\title{
PENGARUH KEPERCAYAAN, POPULARITAS, DAN CITRA MEREK TERHADAP MINAT BELI PRODUK KAMERA SONY
}

\author{
Dheeran Nathani dan Herlina Budiono
}

Program Studi S1 Manajemen Fakultas Ekonomi dan Bisnis Universitas Tarumanagara, Jakarta

Dheeran.115170429@stu.untar.ac.id

\begin{abstract}
The purpose of the research is to 1) find out the influence of Trust on Purchase Intention 2) find out the influence of Popularity on Purchase Intention 3) find out the influence of Brand Image on Purchase Intention. The method used in this study is convenience sampling. Data was taken using an online questionnaire distribution with Google Form as a media of collecting the data. With a total of 115 respondents, research data was processed using smart pls. The results of this study are 1) Trust does not affect Purchase Interest positively and significantly. 2) Popularity does not affect Buying Interest positively and significantly. 3) Brand Image can influence Buying Interest in a positive and significant way.
\end{abstract}

\section{Keywords : Trust, Popularity, Brand Image, Purchase Intention, Camera}

Abstrak: Tujuan dari penelitian yang dibuat adalah untuk 1) Mengetahui pengaruh Kepercayaan terhadap Minat Beli 2) Mengetahui pengaruh Popularitas terhadap Minat Beli 3) Mengetahui pengaruh Citra Merek terhadap Minat Beli. Metode yang digunakan dalam penelitian ini adalah convenience sampling. Pengambilan data menggunakan penyebaran kuesioner online dengan Google Form sebagai media pengumpulan data.. Dengan jumlah responden sebanyak 115 responden. Pengolahan data penelitian menggunakan Smart PLS. Hasil dari penelitian ini yaitu 1) Kepercayaan tidak mempengaruhi Minat Beli secara positif dan signifikan. 2) Popularitas tidak mempengaruhi Minat Beli secara positif dan signifikan. 3) Citra Merek dapat mempengaruhi Minat Beli secara positif dan signifikan.

Kata kunci: Kepercayaan, Popularitas, Citra Merek, Minat Beli, Kamera

\section{LATAR BELAKANG}

Perkembangan dunia fotografi dan videografi saat ini sangat cepat dan terus meningkat setiap saat, sebagian orang beranggapan bahwa kamera saat ini merupakan alat yang dibutuhkan untuk menyimpan foto dan video kegiatan dan momen yang penting. Pada kondisi pasar seperti sekarang ini, konsumen memiliki berbagai alasan untuk memiliki suatu produk termasuk produk kamera yang akan digunakan. Kotler \& Armstrong (2012) menyebutkan dalam sebuah pasar yang kompetitif, pertempuran tidak hanya terletak pada tarif dan produk namun juga pada persepsi konsumen. Image yang kuat serta positif memberikan dampak yang signifikan dalam merebut hati konsumen. Kepercayaan dari seseorang merupakan sebuah hal yang sangat dibutuhkan di dalam mengadakan sebuah penjualan. Kepercayaan merupakan awal dari sebuah faktor yang akan membuat seseorang menjadi memberikan segala sesuatunya untuk mengerjakan atau membeli hal tersebut (Veno, 2013). Popularitas merek atau yang biasa disebut sebagai brand awareness merupakan sebuah hal dimana seseorang dapat mengenali sebuah brand dengan baik. Handayani (2010), mendefinisikan kesadaran merek adalah kemampuan dari konsumen potensial untuk mengenali atau mengingat bahwa suatu merek termasuk ke dalam kategori produk tertentu. Konsumen memandang citra merek sebagai bagian yang terpenting dari suatu produk, karena citra merek mencerminkan tentang suatu produk. Sehingga 
semakin baik dan positif sebuah citra merek maka akan berdampak pada keputusan pembelian oleh konsumen. Memposisikan citra merek sebagai sesuatu yang harus dilakukan oleh hampir seluruh perusahaan, tak terkecuali oleh alat komunikasi. Seiring perkembangan dunia globalisasi, alat komunikasi adalah hal yang penting bagi setiap kalangan masyarakat. Berdasarkan data yang didapat diketahui bahwa pada tahun 2020 camera Sony mengalami penurunan penjualan sebesar 60-70 persen dari tahun 2019, hal ini diakibatkan dengan semakin canggihnya teknologi dari smartphone yang membuat para customer lebih memilih untuk membeli smartphone dibandingkan dengan camera, selain itu dikarenakan pandemi yang membuat pasar dari fotografi menjadi merosot tajam. (Kompas, 2020). Penelitian ini berbeda dari penelitian sebelumnya dikarenakan dalam hal ini kami menggunakan subjek dari camera Sony yang masih jarang untuk diteliti dan dengan menggunakan variabel yang berbeda dari penelitian lain. Berdasarkan latar belakang di atas, maka penelitian ini berjudul "Pengaruh Tingkat Kepercayaan, Popularitas, dan Citra Merek Terhadap Minat Beli Produk Kamera Sony".

\section{KAJIAN TEORI}

Purchase intention Kotler (2016) menjelaskan bahwa minat pembelian adalah perilaku seorang konsumen yang memiliki keinginan untuk memilih atau membeli suatu produk yang berdasar kepada pengalaman, penggunaan, dan keinginan mereka terhadap suatu produk. Menurut Hendro \& Keni (2020) purchase intention merupakan bentuk dari perilaku seorang konsumen yang bersedia melakukan pembelian terhadap suatu produk yang didasari dengan pengalaman, keinginan dan penggunaan terhadap produk. Itu mengartikan bahwa minat pembelian merupakan dorongan untuk membeli dan memperoleh sesuatu barang yang berasal dari dalam diri konsumen dengan adanya proses mengevaluasi sebuah produk sebelum melakukan pembelian maupun transaksi.

Popularity Brogan (2010) Popularity adalah kepopuleran sesuatu di kalangan pengguna teknologi penerbitan yang mudah diakses dan terukur yang memungkinkan banyak jenis transaksi dan Partanto (2001) menyatakan bahwa popularity adalah sering terlihat dan sudah dikenal. Dari pernyataan tersebut dapat dimengerti bahwa popularitas dapat dimengertikan dengan seberapa banyak orang mengetahui produk atau brand tersebut.

Trust Menurut Sirdesmukh (2002) kepercayaan merupakan keyakinan satu pihak mengenai maksud dan perilaku pihak yang lainnya. Menurut Delgado (2005) berpendapat bahwa trust ialah sebuah perasaan dimana konsumen merasa terlindungi dan merasa percaya di dalam mengkonsumsi atau menggunakan produk tersebut. Menurut Hendri, \& Budiono, H. (2021) kepercayaan adalah penentu perilaku interpersonal yang berhubungan dengan keyakinan tentang integritas, kebajikan, kemampuan, dan prediktabilitas seseorang. Menurut Hendro \& Keni (2020) trust adalah keyakinan atau harapan yang dimiliki oleh individu maupun kelompok individu dalam melakukan transaksi dengan tujuan merek tersebut dapat memenuhi niat dan harapan konsumsi. Dapat disimpulkan bahwa trust yang merupakan sebuah bentuk keyakinan atau suatu harapan yang dimiliki oleh seorang konsumen atau sekelompok konsumen dalam melakukan transaksi dengan harapan prodok tersebut dapat memenuhi keinginan konsumsi.

Brand image Keller (1993) mengungkapkan bahwa brand image didefinisikan sebagai persepsi mengenai merek yang dicerminkan dari asosiasi merek yang terdapat pada ingatan konsumen. Menurut Aaker dan Biel (1993) citra merek adalah penilaian konsumen terhadap merek tersebut dalam sebuah pasar. Menurut Hendri, \& Budiono, H. (2021) Brand Image adalah persepsi konsumen tentang suatu merek, persepsi tersebut akan membuat suatu merek menjadi istimewa serta berbeda dibandingkan merek lain. Menurut I Made Genta Wedangga \& Keni 
(2020) Brand Image merupakan serangkaian asosiasi merek yang konsumen ingat dalam memori pikirannya. Hendro \& Keni (2020) brand image merupakan persepsi dalam memori konsumen yang terbentuk melalui tingkat rasional dan interpretasi emosional terhadap merek dan penawaran yang diberikan oleh perusahaan. Dapat dimengerti bahwa brand image adalah persepsi dalam memori seorang konsumen atau sekelompok konsumen yang terbentuk dari tingkat rasional dan interpretasi emosial terhadap produk dan penawaran yang diberikan oleh sebuah perusahaan.

Kaitan antar Kepercayaan dan Minat beli Pada penelitian Liu (2017) mengutarakan bahwa terdapat pengaruh positif yang kuat antara trust terhadap minat pembelian. Lee (2011) dalam penelitiannya mengatakan bahwa terdapat pengaruh positif antara trust dengan purchase intention. Berdasarkan penelitian yang dilakukan oleh Anwar (2014) didapatkan hasil bahwa trust berpengaruh positif dan tidak signifikan terhadap purchase intention. Menurut Veronica \& Rodhiah (2021) adanya nilai sosialisasi individu yang berada di dalam suau negara asalnya sehingga konsumen bertindak sebagai seseorang individu dengan berdasarkan pada nilai budaya negara asal mereka yang mempengaruhi niat pembelian dalam melakukan suatu keputusan. Menurut Hendro \& Keni (2020) dengan adanya nilai kepercayaan terhadap suatu produk perusahaan dapat memengaruhi niat pembelian bagi seorang konsumen. Dapat dimengerti bahwa Kepercayaan dapat memberikan pengaruh terhadap daya tarik suatu produk dan situs terhadap niat pembelian konsumen.

Kaitan antar Popularitas dan Minat Beli Berdasarkan penelitian yang dilakukan oleh Alatas (2018) didapatkan hasil bahwa popularity berpengaruh positif terhadap purchase intention, dikarenakan dengan adanya popularitas, maka akan membuat seseorang menjadi lebih percaya dan mengenal produk tersebut. Berdasarkan penelitian yang dilakukan oleh Faraditta (2015) didapatkan hasil bahwa popularitas memberikan pengaruh terhadap purchase intention, dimana di dalam popularitas ini dipengaruhi oleh berbagai faktor. Berdasarkan penelitian yang dilakukan oleh Dwipayani (2013) didapatkan hasil bahwa popularitas berpengaruh positif terhadap purchase intention. Berdasarkan penelitian yang dilakukan oleh Mulyati (2020) didapatkan hasil bahwa popularity berpengaruh positif terhadap purchase intention.

Kaitan antar Citra merek dan Minat Beli. Pada penelitian yang dilakukan oleh Farzin dan Fattahi (2018) ditemukannya pengaruh positif antara brand image terhadap purchase intention. Dalam proses pembentukan brand image yang baik di dalam benak konsumen maka akan mempengaruhi juga terhadap keputusan pembelian bagi konsumen. Lebih lanjut, Jalilvand dan Samiei (2012) mengatakan bahwa brand image mempengaruhi purchase intention. Dengan meningkatkannya citra merek dalam suatu perusahaan maka akan meningkatnya juga niat pembelian konsumen terhadap produk perusahaan. Dalam penelitian yang didapatkan oleh Fajariah (2015) dalam penelitian tersebut didapatkan hasil perceived intention berpengaruh positif dan signifikan terhadap brand image dan brand loyalty. Berdasarkan penelitian yang dilakukan oleh Kurniawan (2018) didapatkan hasil bahwa brand image berpengaruh positif dan signifikan terhadap purchase intention. Menurut Yonita, T. \& Budiono, H. (2020) Brand Image memiliki pengaruh positif terhadap Purchase Intention. Hendro \& Keni (2020) menyatakan dalam memiliki citra merek yang baik, perusahaan harus dapat memaksimalkan peluang yang ada. Hal ini dapat membuat konsumen semakin yakin dengan produk dan layanan yang diberikan oleh perusahaan. Berdasarkan penelitian yang dilakukan oleh Resmawa (2017) didapatkan hasil bahwa brand image terbukti mempunyai pengaruh positif dan signifikan terhadap purchase intention. 
Berdasarkan kajian teori yang tertera di atas, maka model penelitian yang dapat dirumuskan untuk penelitian ini adalah sebagai berikut:



Gambar 1. Model Penelitian

$\mathrm{H}_{1:}$ Trust berpengaruh positif terhadap purchase intention

$\mathrm{H}_{2}$ : Popularity berpengaruh positif terhadap purchase intention

$\mathrm{H}_{3}$ : Brand image berpengaruh positif terhadap purchase intention

\section{METODOLOGI}

Dalam penelitian ini, peneliti akan menggunakan desain penelitian deskriptif dengan pendekatan cross-sectional. Populasi dari penelitian ini antara lain pelanggan produk kamera SONY di Jakarta. Peneliti menggunakan non-probability sampling, lebih spesifiknya menggunakan convenience sampling. Desain penelitian terdiri atas penelitian eksploratif dan konklusif. Penelitian eskploratif bertujuan untuk memberikan informasi dan pemahaman tentang masalah yang dihadapi oleh peneliti, penelitian eksploratif digunakan untuk mendefinisikan masalah, mengindentifikasi tindakan yang relevan. Sedangkan penelitian konklusif bertujuan untuk menguji hipotesis dan memeriksa hubungan tertentu dari variabel-variabel yang ada. Kemudian didalam desain penelitian konklusif terbagi menjadi dua yaitu deskriptif dan kausal. Penelitian deskriptif digunakan untuk mendeskripsikan karakteristik variabel-variabel yang berkaitan dengan pelanggan, organisasi. Dan penelitian kausal digunakan untuk menguji apakah satu suatu variabel dapat menyebabkan variabel lain berubah dan mendapatkan bukti hubungan sebab-akibat. Perbedaan antara penelitian deskriptif dan kausal yaitu, dalam penelitian kausal terdapat variabel yang dimanipulasi dan didalam penelitian deskriptif tidak ada variabel yang dimanipulasi. Responden yang terkumpul dalam penelitian ini sebanyak 115. Responden ini didominasi dengan berjenis kelamin laki-laki yaitu sebanyak 80 responden $(6, .6 \%)$, berusia 19 - 23 tahun yaitu sebanyak 45 responden $(39,1 \%)$, berdomisili di Jakarta Utara sebanyak 37 responden $(32,2 \%)$.

\section{HASIL UJI STATISTIK}

Hasil Validitas

Tabel 1. Hasil nilai Average Variance Extracted (AVE)

\begin{tabular}{|c|c|}
\hline Variabel & Average Variance Extracted \\
\hline Kepercayaan & 0,620 \\
\hline
\end{tabular}




\begin{tabular}{|c|c|}
\hline Popularitas & 0,631 \\
\hline Citra Merek & 0,648 \\
\hline Minat Beli & 0,654 \\
\hline
\end{tabular}

Sumber: Pengolahan Data SmartPLS

Hasil pengujian ini menunjukkan bahwa variabel yang diukur telah memenuhi syarat loading factor yaitu di atas 0,7 dan nilai AVE di atas 0,5. Sehingga dapat dinyatakan valid. Berikutnya nilai composite reliability dan cronbach's alpha masing-masing item telah memenuhi syarat yaitu di atas 0,7 . Sehingga dapat disimpulkan bahwa semua variabel dinyatakan reliabel.

Tabel 2. Hasil nilai Loading Factor

\begin{tabular}{|c|l|c|}
\hline \multicolumn{2}{|c|}{ Indikator } & $\begin{array}{c}\text { Loading } \\
\text { factor }\end{array}$ \\
\hline CM1 & menyukai merek Sony & 0,786 \\
\hline CM2 & maerasa bahwa citra merek Sony unik & 0,742 \\
\hline CM3 & $\begin{array}{l}\text { Menghargai merek Sony (seperti : melihat Kamera Sony sebagai kamera } \\
\text { professional) }\end{array}$ & 0,880 \\
\hline KE1 & produk Sony memiliki Keandalan (seperti : durabilitas, dan kualitas) & 0,767 \\
\hline KE2 & $\begin{array}{l}\text { Merasa Percaya bahwa produk kamera Sony jujur (seperti : spesifikasi yang di } \\
\text { berikan dan hasil yang dikeluarkan) }\end{array}$ & 0,772 \\
\hline KE3 & $\begin{array}{l}\text { Peduli dengan produk Sony (seperti : mengikuti kemajuan kamera Sony, dan } \\
\text { memahami spesifikasi yang berada di seri yang dikeluarkan) }\end{array}$ & 0,771 \\
\hline KE4 & $\begin{array}{l}\text { Produk Sony memiliki kredibilitas (seperti kualitas gambar dan kenyamanan } \\
\text { saat digunakan) }\end{array}$ & 0,837 \\
\hline MB1 & Memiliki kemungkinan besar untuk membeli produk kamera Sony & 0,785 \\
\hline MB2 & Memiliki keinginan besar untuk membeli produk kamera Sony & 0,759 \\
\hline MB3 & Akan merekomendasikan produk kamera Sony kepada teman atau keluarga & 0,878 \\
\hline PO1 & Produk kamera Sony memiliki Daya tarik fisik & 0,744 \\
\hline PO2 & Produk kamera Sony memiliki keahlian tersendiri & 0,750 \\
\hline PO3 & Produk Sony memiliki Karakteristik sendiri & 0,881 \\
\hline Sumb
\end{tabular}

Sumber: Pengolahan Data SmartPLS

Berdasarkan hasil dari di atas, data telah menunjukkan bahwa seluruh indikator yang digunakan memiliki nilai loading factor di atas 0,60. Hal ini dapat disimpulkan bahwa data penelitian ini reliabel dan valid karena memenuhi kriteria yang ada.

Tabel 3. Hasil pengujian Reliabilitas

\begin{tabular}{|l|c|c|}
\hline \multicolumn{1}{|c|}{ Variabel } & Cronbach's Alpha & Composite Reliability \\
\hline Citra merek & 0,725 & 0,846 \\
\hline Kepercayaan & 0,795 & 0,867 \\
\hline Minat Beli & 0,733 & 0,850 \\
\hline Popularity & 0,703 & 0,836 \\
\hline
\end{tabular}


Sumber: Pengolahan Data SmartPLS

Berdasarkan hasil analisis Cronbach's Alpha, data tersebut menyatakan bahwa nilai Cronbach's Alpha dan Composite Reliability pada setiap indikator memiliki nilai yang lebih besar dari 0,7, maka dengan ini dapat dikatakan bahwa seruh variabel yang digunakan di dalam penelitian ini reliabel.

Tabel 4. Hasil uji $\mathrm{R}^{2}$

\begin{tabular}{|c|c|}
\hline Variabel & $\mathbf{R}^{\mathbf{2}}$ \\
\hline Minat Beli & 0,744 \\
\hline
\end{tabular}

Sumber: Pengolahan Data SmartPLS

Berdasarkan hasil pengujian R-square yang terdapat di tabel di atas dapat di jelaskan bahwa nilai R-square variabel Minat Beli sebesar 0,744 yang berarti sebesar 7,44\%, dapat disimpulkan bahwa nilai R-square dari variabel Minat Beli tergolong tinggi.

Tabel 5. Hasil uji $Q^{2}$

\begin{tabular}{|c|c|}
\hline Variabel & $\mathbf{Q}^{\mathbf{2}}$ \\
\hline Minat Beli & 0,474 \\
\hline
\end{tabular}

Sumber: Pengolahan Data SmartPLS

Berdasarkan hasil pengujian Predictive Relevance yang terdapat di tabel di atas dapat di jelaskan bahwa nilai Predictive Relevance variabel Minat Beli sebesar 0,474. Dapat disimpulkan bahwa nilai Predictive Relevance dari variabel yang ada menyatakan bahwa nilai tersebut cukup besar.

Penelitian ini juga melakukan uji path coefficient untuk mengetahui hubungan antar variabel independen dan dependen apakah positif atau negatif. Berikut di bawah ini hasil dari uji path coefficient yang terdapat di dalam uji bootstrapping yang ditampilkan dalam bentuk tabel.

Tabel 6. Hasil pengujian Path Coefficients

\begin{tabular}{|c|c|c|c|}
\hline Variabel & Path Coefficient & t-statistics & p-values \\
\hline Citra Merek -> Minat Beli & 0,651 & 7,075 & 0,000 \\
\hline Kepercayaan -> Minat Beli & 0,259 & 0,189 & 0,074 \\
\hline Popularitas -> Minat Beli & $-0,003$ & 0,021 & 0,983 \\
\hline
\end{tabular}

Sumber: Pengolahan Data SmartPLS

Dari hasil pengujian path coefficient yang ditampilkan dalam Tabel 6, dapat disimpulkan bahwa Citra Merek memiliki nilai koefisien terbesar dengan arah yang positif dalam mempengaruhi Minat Beli dengan nilai sebesar 0,651. Kemudian, Kepercayaan dengan nilai koefisien terbesar kedua dan arah yang positif yaitu sebesar 0,259. Dan yang terakhir Popularitas dengan arah yang negatif yaitu sebesar $-0,003$. Hasil uji ini juga mengindikasikan bahwa tidak semua variabel dalam penelitian ini terbukti secara positif dan signifikan memiliki pengaruh terhadap variabel Minat Beli. 
Pada uji hipotesis, $\mathrm{H}_{1}$ menunjukkan bahwa variabel Kepercayaan terbukti berpengaruh secara positif namun tidak signifikan terhadap Minat Beli dengan nilai $p$-value sebesar 0,074 dan nilai $t$-statistics sebesar 0,189 . Maka dapat disimpulkan bahwa $\mathrm{H}_{1}$ tidak diterima.

Uji hipotesis $\mathrm{H}_{2}$, menunjukkan bahwa variabel Popularitas terbukti tidak berpengaruh secara positif terhadap Minat Beli dengan nilai $p$-value sebesar 0,983 dan nilai $t$-statistics sebesar 0,021. Maka dapat di simpulkan bahwa $\mathrm{H}_{2}$ tidak diterima.

Uji hipotesis $\mathrm{H}_{3}$, menunjukkan bahwa variabel Citra Merek terbukti tidak berpengaruh secara positif terhadap Minat Beli dengan nilai $p$-value sebesar 0,000 dan nilai $t$-statistics sebesar 7,075. Maka dapat di simpulkan bahwa $\mathrm{H}_{3}$ tidak diterima.

\section{PEMBAHASAN}

Tujuan dari penelitian ini adalah untuk mengetahui pengaruh Kepercayaan,popularitas dan citra merek terhadap minat beli produk kamera sony. Pemilihan perusahaan sony untuk di teliti dikarenakan dengan adanya penurunan dalam penjualan kamera sony sebesar $60 \%-70 \%$ pada tahun 2020.Karakteristik responden yang digunakan pada penelitian ini adalah orang yang memiliki kamera sony, merupakan pengguna kamera sony, dan mengetahui tentang kamera sony. Berdasarkan dari penelitian ini, terdapat 3 hipotesis yaitu, Kepercayaan berpengaruh positif terhadap minat beli $\left(\mathrm{H}_{1}\right)$, Popularitas berpengaruh positif terhadap minat beli $\left(\mathrm{H}_{2}\right)$, Citra Merek berpengaruh positif terhadap minat beli $\left(\mathrm{H}_{3}\right)$. Penelitian ini menggunakan skala likert untuk mempelajari respon yang di dapat dari para responden. Penelitian ini menggunakan desain penelitian deskriptif dengan pendekatan cross-sectional. Populasi dari penelitian ini antara lain pelanggan produk kamera SONY di Jakarta. Penelitian ini menggunakan non-probability sampling, lebih spesifiknya menggunakan convenience sampling. Pengolahan data pada penelitian ini menggunakan Smart-PLS. Berdasarkan dari hasil yang di dapat dari penelitian ini, dapat dinyatakan bahwa Kepercayaan berpengaruh secara positif namun tidak secara signifikan terhadap Minat Beli kamera $\left(\mathrm{H}_{1}\right)$, Popularitas berpengaruh secara negatif dan tidak signifikan terhadap Minat Beli kamera SONY $\left(\mathrm{H}_{2}\right)$, Citra Merek berpengaruh secara positif dan signifikan terhadap Minat Beli kamera SONY $\left(\mathrm{H}_{3}\right)$.

\section{KESIMPULAN}

Berdasarkan hasil yang telah diperoleh dan di analisis maka hasil penelitian ini dapat disimpulkan sebagai 1) Kepercayaan berpengaruh secara positif namun tidak secara signifikan terhadap Minat Beli kamera SONY di Jakarta dengan nilai t-statistic sebesar 0,189 dan nilai pvalue sebesar 0,074. Dari hasil pengujian yang telah dibuat dapat disimpulkan bahwa kepercayaan seorang konsumen tidak berpengaruh terhadap minat beli produk kamera yang telah dikeluarkan oleh SONY. 2) Popularitas berpengaruh secara negatif dan tidak signifikan terhadap Minat Beli kamera SONY di Jakarta dengan nilai t-statistic sebesar 0,021 dan nilai p-value sebesar 0,983. Dari hasil pengujian produk kamera SONY dapat disimpulkan bahwa penilaian Popularitas seseorang terhadap kamera SONY tidak berpengaruh terhadap minat beli kamera tersebut. 3) Citra Merek berpengaruh secara positif dan signifikan terhadap Minat Beli kamera SONY di Jakarta dengan nilai $t$-statistic sebesar 7,075 dan nilai $p$-value sebesar 0,000 . Dari hasil pengujian yang telah dibuat dapat disimpulkan bahwa seorang konsumen dapat mempengaruhi minat beli konsumen tersebut terhadap produk kamera SONY. Untuk peneliti berikutnya, penelitian ini harap dapat dikembangkan lagi. Baik dengan menambah variabel lainnya, mengambil jumlah responden yang lebih banyak dan memperluas jangkauan wilayah, tidak hanya di Jakarta melainkan di luar Jakarta. Berdasarkan hasil yang telah diperoleh dari penelitian 
yang dilakukan, maka peneliti memberikan beberapa saran yang mungkin dapat digunakan untuk pihak lain yang ingin meneliti subjek yang sama. Dapat diketahui bahwa Kepercayaan dan Popularitas produk kamera SONY terhadap Minat Beli sudah baik dan diharapkan dapat ditingkatkan dalam waktu jangka panjang dengan cara mendengar saran dan kritik yang diberikan oleh para pengguna produk kamera SONY, menepati janji yang diberikan oleh merek SONY terhadap produk yang dikeluarkan, menjadikan merek SONY jujur dan terbuka terhadap produk yang dikeluarkan, memberikan kesan pertama yang baik dengan setiap pengeluaran produk kamera yang baru, meyakinkan para konsumen bahwa merek SONY akan menjadi pilihan yang tepat untuk mereka saat mencari kamera professional. Citra merek yang di rasakan oleh responden terhadap produk kamera SONY cukup baik, dan disarankan untuk meningkatkan dan mempertahankan kualitas Citra merek agar dapat meningkatkan Minat Beli konsumen terhadap produk kamera SONY dengan cara melakukan promosi yang efektif dan efisien, mencari target pasar yang benar saat melakukan promosi, menggunakan jasa influenser, memanfaat kan media sosial, meningkatkan kualitas produk dan layanan yang diberikan kepada para konsumen. Peneliti menyarankan Popularitas untuk produk kamera SONY ditingkatkan dengan cara menggunakan influenser untuk mempromosikan produk merek SONY, membuat website dan sosial media SONY menarik dan mudah di akses oleh semua kalangan, mengikuti event agar merek SONY dapat dikenal oleh masyarakat, memberikan reward kepada para konsumen supaya Popularitas yang didapatkan dapat meningkatkan Minat Beli produk kamera SONY pada saat yang akan datang. Bagi penelitian selanjutnya dapat meningkatkan jumlah variabel yang digunakan, selain dari variabel yang telah digunakan pada penelitan ini.

\section{DAFTAR PUSTAKA}

Aaker, D. A., \& Biel, A. L. (Eds.). (1993). Brand equity \& advertising: Advertising's role in building strong brands. Lawrence Erlbaum Associates, Inc.

Al,Burry, M Dahlan dan Pius Partanto. 2001. Kamus Ilmiah Populer. Surabaya:Arkola.

Alatas, S. L., \& Tabrani, M. (2018). Pengaruh Celebrity Endorser Terhadap Purchase Intention Melalui Brand Credibility. Jurnal Manajemen, 9(1), 91-105.

Anwar, Gentasri, 1995. Teknik dan Seni Berpidato, Jakarta : PT Rineka Cipta.

Brogan, C. (2010). Social Media 101: Tactics and Tips to Develop Your Business. Online. Hoboken, New Jersey: John Wiley \& Sons, Inc.

Delgado-Ballester, E., \& Munuera-Alemán, J. L. (2005). Does brand trust matter to brand equity? Journal of Product and Brand Management, 14(3), 187-196. https://doi.org/10.1108/10610420510601058

Fajariah, N., Thoyib, A., \& Rahman, F. (2016). Pengaruh brand awareness, perceived quality, Dan brand image terhadap brand loyalty pada Generasi Y Di Indonesia. Jurnal Aplikasi Manajemen, 14(3), 471-480. https://doi.org/10.18202/jam23026332.14.3.08

Farzin, M., \& Fattahi, M. (2018). eWOM through social networking sites and impact on purchase intention and brand image in Iran. Journal of Advances in Management Research, 15(2), 161-183. https://doi.org/10.1108/JAMR-052017-0062

Handayani, Desy. (2010). Brand Operation. Jakarta: Esensi.

Hendri, \& Budiono, H. (2021). Pengaruh Brand Image, Brand Trust, EWOM terhadap Purchase Intention pada produk H\&M pada masa pandemi Covid-19. Jurnal Manajerial dan Kewirausahaan, 3(2), 371-379.

Hendro, H., \& Keni, K. (2020). EWOM Dan trust sebagai Prediktor terhadap purchase intention: Brand image sebagai Variabel Mediasi. Jurnal Komunikasi, 12(2), 298. https://doi.org/10.24912/jk.v12i2.7760 
Halilvand, M. R., \& Samiei, N. (2012). The effect of electronic word of mouth on brand image and purchase intention: An empirical study in the automobile industry in Iran. Marketing Intelligence and Planning, 30(4), 460-476. https://doi.org/10.1108/02634501211231946

Keller (1993). Conceptualizing, measuring, and managing customer-based brand equity. Journal of Marketing. 57:1-22

Kompas Cyber Media. (2021, January 13). Penjualan Kamera digital 2020 Turun Tajam, webcam Naik. KOMPAS.com. https://tekno.kompas.com/read/2021/01/13/15080027/penjualan-kamera-digital-2020turun-tajam-webcam-naik?page $=$ all

Kotler P dan Gary Amstrong. (2012). Principle of marketing. Global edition, 14 edition, pearson education.

Kurniawan H, A., dan F. Indriani, (2018) "pengaruh product knowledge, perceived quality, perceived risk, dan perceived value terhadap purchase intention pada motor kawasaki ninja 250 fi di kota semarang," Diponegoro Journal of Management, vol. 7, no. 4, pp. 346-358, Jun. [Online]. \#\#plugins.citationFormats.ieee.retrieved\#\#

Lee, J., Park, D. H., \& Han, I. (2011). The different effects of online consumer reviews on consumers' purchase intentions depending on trust in online shopping malls: An advertising perspective. Internet Research, 21(2), 187206. https://doi.org/10.1108/10662241111123766

Liu, F., Xiao, B., Lim, E. T. K., \& Tan, C. W. (2017). The art of appeal in electronic commerce: Understanding the impact of product and website quality on online purchases. Internet Research, 27(4), 752-771. https://doi.org/10.1108/IntR-09-2016-0280

Praptono, L. H., \& Haryanto. (2013). Purchase Intention:Apakah Tampilan Website Berpengaruh?.

Resmawa (2017) Pengaruh brand image Dan product knowledge terhadap purchase intention dengan green price sebagai moderating Variabel pada Produk the body shop Di Surabaya. (n.d.). Jurnal Aplikasi Manajemen, Ekonomi dan Bisnis. https://jameb.stimlasharanjaya.ac.id/JAMEB/article/view/20

Sirdesmukh (2002). Consumer trust, value, and loyalty in relational exchanges. ResearchGate.https://www.researchgate.net/publication/233894779_Consumer_Trust_V alue_and_Loyalty_in_Relational_Exchanges

Veronica, \& Rodhiah. (2021). PENGARUH PRIVACY, SOCIAL INFLUENCE TERHADAP ONLINE PURCHASE INTENTION: TRUST SEBAGAI VARIABEL MEDIASI, Jurnal Komunikasi, 5(2), 235-246. https://doi.org/10.24912/jmieb.v5i2.9657

Wedangga, I. M., \& Keni. (2020). Brand image Dan country of origin untuk Memprediksi purchase decision Konsumen : Variabel perceived quality Sebagai Variabel Mediasi. JurnalManajemenBisnisdanKewirausahaan,4(6),276. https://doi.org/10.24912/jmbk.v4i6.9793

Yonita, T., \& Budiono, H. (2020). Pengaruh Ewom Terhadap Brand Image Dan Purchase Intention Produk Innisfree Di Jakarta, Jurnal Manajerial dan Kewirausahaan. 2(1), 152161. 